\title{
OF GREENISH ENCYCLIA: NATURAL VARIATION, TAXONOMY, CLEISTOGAMY, AND A COMMENT ON DNA BARCODING
}

\author{
Franco Pupulin ${ }^{1-5} \&$ Diego Bogarín ${ }^{1-4}$ \\ ${ }^{1}$ Lankester Botanical Garden, University of Costa Rica, P. O. Box 1031-7050 Cartago, Costa Rica \\ ${ }^{2}$ Harvard University Herbaria, Cambridge, Massachusetts 02138 USA \\ ${ }^{3}$ Marie Selby Botanical Gardens, Sarasota, Florida 34236 USA \\ ${ }^{4}$ Andean Orchids Research Center "Ángel Andreetta”, University Alfredo Pérez Guerrero, Ecuador \\ ${ }^{5}$ Corresponding author: franco.pupulin@ucr.ac.cr
}

AbStRact. The species-level taxonomy of Encyclia has been disputed considerably because of the great morphological similarity among many of the taxa, particularly in the complex of species related to $E$. chloroleuca and $E$. gravida, characterized by small, greenish flowers. Current phylogenetic results are insufficient to assess the natural lineages of the greenish species of Encyclia, and species concepts in this group are discussed here independently from previous schemes of classification and current nomenclatural uses. In Mesoamerica, traditional taxonomic approaches shifted from broad views of species circumscriptions to the recognition of a large number of finely split taxa. However, the relative paucity of specimens available for study led both approaches to fail to appreciate the range of natural variation, with the consequence of nomenclatural inflation and misunderstanding of species diversity. On the basis of a better sample, we reduce the supposedly rare and variable E. amanda to synonymy of E. chloroleuca and discuss the case of cleistogamous individuals of Encyclia referred to E. gravida. On the basis of floral morphology, we suggest that the few documented records of $E$. gravida may simply represent self-pollinating forms belonging to different taxa.

RESUMEN. La necesidad de conceptos específicos delimitados rigurosamente ha sido enfatizada para contar con inventarios de biodiversidad más certeros. Sin embargo, mientras el número de nuevos organismos descritos crece con un ritmo que no tiene antecedentes, nuestros conocimientos de mucho de los antiguos y nuevos taxones está todavía basado en un número extremamente reducido de muestras, con una apreciación en el mejor de los casos reducida de su variación natural. Aun cuando se consideren en su circunscripción más estrecha, cercana al concepto original propuesto por Hooker (es decir, plantas con pseudobulbos piriformes, una inflorescencia terminal que no nace de una espata, hojas coriáceas a carnosas, un labio membranáceo generalmente provisto de lóbulos laterales bien desarrollados que envuelven la columna, y un callo forcipato en el disco del labelo), las "verdaderas" especies de Encyclia siguen siendo un grupo taxonómico difícil. Esto es particularmente evidente para un amplio complejo de especies emparentadas con E. chloroleuca, caracterizadas por flores pequeñas y en su mayoría verdosas, que se distribuyen en todo el Neotrópico. Las interpretaciones taxonómicas tradicionales de este grupo en la región mesoamericana oscilan entre el reconocimiento de 13 taxones finamente partidos y la taxonomía más conservadora de Ames y sus colegas en Harvard, quienes adoptaron conceptos amplios y en el grupo reconocieron solamente cuatro especies (con cinco subespecies). Ambas interpretaciones, sin embargo, se basaron fundamentalmente en el estudio de material escaso, a menudo unas pocas colecciones por cada país, según un sistema que ha prevenido la apreciación de la variación natural y últimamente llevó los taxónomos hacia una inflación en la nomenclatura o, alternativamente, a un concepto generalmente equivocado de la diversidad de las especies. En Mesoamérica, hoy en día reconocemos nueve especies de Encyclia verdosas (una de ellas probablemente no descrita) algunas de las cuales se extienden a Suramérica. La taxonomía de los taxones Andinos de este grupo, sin embargo, necesita urgentemente de revisión. En los últimos años, la secuenciación del genoma de las plantas, sobretodo a través de los códigos de barras, se ha reconocido como una poderosa herramienta para evaluar la congruencia de los conceptos específicos y descubrir taxones crípticos difíciles de separar con métodos taxonómicos tradicionales. Sin embargo, los códigos de barras por si solos nunca son suficiente para describir una nueva especie, aunque a un cierto punto códigos muy claramente divergentes 
pueden utilizarse (con otros conjuntos de datos) como base para decisiones nomenclatoriales. Para priorizar cuales "morfoespecies" y cuales individuos deben ser secuenciados en complejos de especies problemáticos, el análisis del rango de variación intra- e interespecífico constituye un primer paso necesario para ubicar los códigos de barras en el contexto de un acercamiento taxonómico complejo, que finalmente utilice las técnicas basadas en el ADN en conjunto con otras disciplinas, tales como la filogeografía, la morfología comparativa, la genética de poblaciones, la ecología, el desarrollo y la biología reproductiva, para delimitar de forma mejor las unidades de la diversidad de orquídeas.

KEY WORDS: Orchidaceae, Laeliinae, Encyclia, Central America, taxonomy, cleistogamy

The need for rigorously delimited species concepts has been emphasized for the accuracy of biodiversity inventories. However, while the number of newly described organisms increases at an unprecedented rate, our knowledge of many of the old and new taxa is still based on a minimal number of samples. This is particularly evident in the case of tropical orchids, an impressively diverse group of organisms, which are in many cases only fragmentarily known through a few records randomly collected over their geographic ranges. The proliferation of synonyms in species descriptions, which traditionally plagued orchid taxonomy, is largely due to the difficulty of appreciating the range of natural variation among and between populations on the basis of the limited available samples, particularly in the case of taxa with broad distributions. Before the advent of large floristic projects such as Flora Neotropica in the 1960s (to date, only the genera Bulbophyllum, Epidendrum, Isochilus, Mormodes, and Vanilla have been scheduled for inclusion) and Flora Mesoamericana in the last 15 years, floristics have been published mostly on a national or local scale, and widespread taxa have often received a different name in each of the countries where they naturally occur.

In the case of the Neotropical orchid genus Encyclia Hook., the interest of systematic botanists mostly focused in the past on a more convenient - or more natural - way to circumscribe the genus (e.g., Lindley 1842, 1853, Ames et al.1936, Dressler, 1961, 1984, Dressler \& Pollard 1971, 1974, Withner 1998, 2001, van den Berg et al. 2000, Higgins 1998 ,Higgins et al. 2003), but the task of describing the diversity of Encyclia was essentially achieved in a floristic context with little or no attention given to any scheme of relationships among species. Joseph D. Hooker established Encyclia in 1828 based on a species native to Rio de Janeiro, Brazil, and separated it from "the splendid species of Cattleya," at that time including only three species (Hooker 1828). Hooker's Encyclia viridiflora, the type species for the genus, is indeed a peculiar and poorly known plant with many unique characteristics compared to its close relatives. These include non-resupinate flowers, a short column, the lateral lobes of the lip almost completely fused with the midlobe, and a nonforcipate basal callus (Hooker, 1828, Withner 1996; Fig. 1). By the midpoint of the 19th century, under the authority of John Lindley, the genus was merged under Epidendrum L., and the type species was assigned to

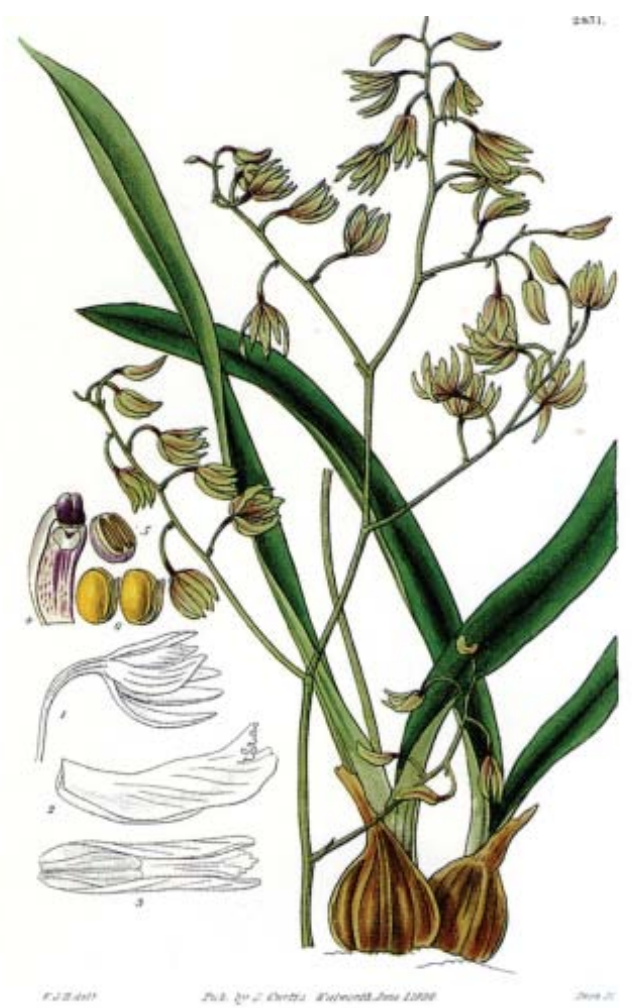

Figure 1. Original illustration of Encyclia viridiflora, from Curtis's Botanical Magazine 1828, pl. 2851. 


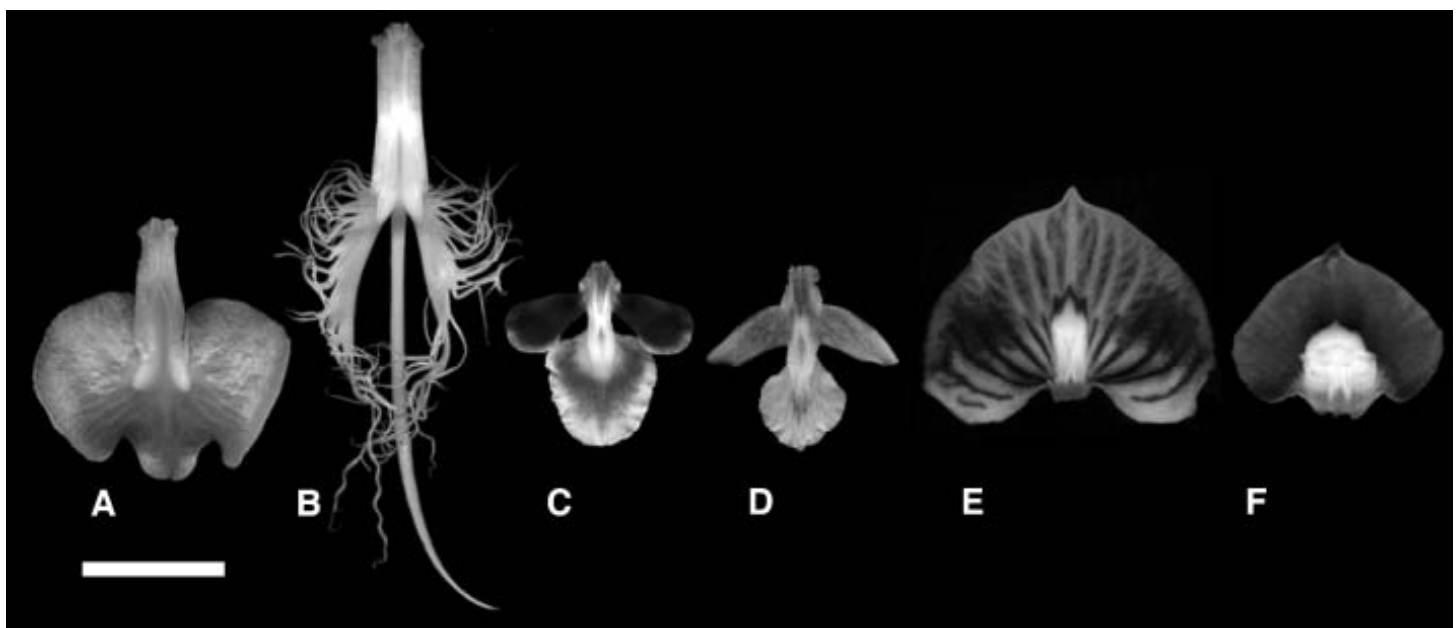

Figure 2. Labella of Epidendrum, Encyclia and Prosthechea species. A - Epidendrum storkii; B - E. ciliare; C - Encycliamooreana; D - E. chloroleuca; E -Prosthechea cochleata; F - P. spondiada. Scale bar $=1 \mathrm{~cm}$.

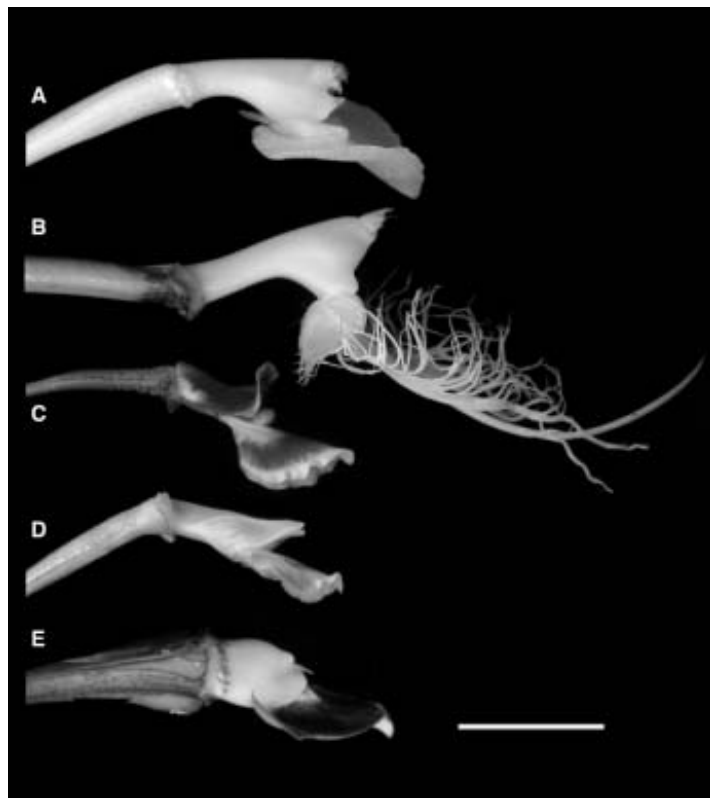

FiguRE. 3. Lateral views of the gynostemia and labella of Epidendrum, Encyclia and Prosthechea species, showing various degrees of adnation between column and lip. A - Epidendrum storkii; B - E. ciliare; C - Encyclia mooreana; D - E. chloroleuca; E - Prosthechea spondiada. Scale bar $=1 \mathrm{~cm}$.

E. subgenus Encyclium Lindl. section Hymenochyla Lindl. (Lindley 1831, 1842, 1853). Despite attempts to revive Encyclia by Rudolf Schlechter (1914, 1918, 1922, 1923), it was not until 1961 when Robert L.

Dressler offered conclusive evidence to recognize the

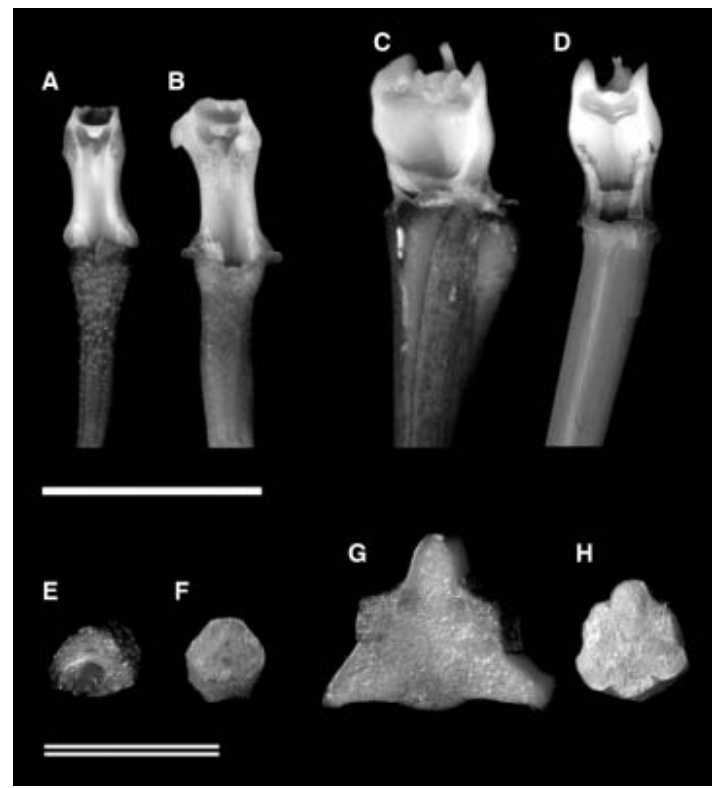

Figure. 4. Columns and sections through the ovaries of Epidendrum, Encyclia and Prosthechea species. A-D, Columns. A - Encyclia mooreana; B - E. chloroleuca; C - Prosthechea spondiada; D - P. cochleata; E-H, Transverse sections through the ovaries. E - Encyclia mooreana; $\mathrm{F}$ - E. chloroleuca; G - Prosthechea spondiada; H - P. cochleata. Scale bar $=1 \mathrm{~cm}$; double bar $=5 \mathrm{~mm}$.

distinctness of the genus and the need to segregate it from Epidendrum (Dressler 1961; Fig. 2-3). However, even when the genus is considered in its narrower circumscription approximating the original concept by Hooker (Withner 1996), today widely 
accepted notwithstanding the removal of the large bulk of species now assigned to Prosthechea Knowl. \& Westc. (Higgins 1998; Fig. 4), the 'true' Encyclia species still form a difficult taxonomic group, and the identity of many of the species in the genus remains confused (see, for example, Dressler 2004 vs. Withner 1998, 2001).

\section{The taxonomy of greenish Encyclia}

Species-level taxonomy of Encyclia has been widely disputed, largely because of the great morphological similarity among many of the taxa particularly in the large complex of species related to $E$. chloroleuca and E. gravida (Lindl.) Schltr., which are characterized by small and mostly greenish flowers and the application of old names often based on poorly defined species concepts. We refer to these complexes here by the collective name of 'greenish encyclias'. 'Green' is not in any way a taxonomic category, and current phylogenetic results are insufficient to assess the natural lineages of the greenish species, so we feel free to discuss this group independently from any previous scheme of classification and current nomenclatural uses.

With several exceptions, which are easy to identify by unique sets of floral and vegetative features (such as the distinctive $E$. adenocaula (Llave \& Lex.) Schltr., E. cordigera (Kunth) Dressler, or $E$. phoenicea (Lindl.) Neumann), species of Encyclia commonly share a common, uniform, and generalized morphological scheme. The plants are provided with ovoid pseudobulbs that bear two or three (rarely four) coriaceous leaves at the apex; inflorescences are frequently paniculate and variable in length even at different stages of the same individual, with the rachis and the pedicellate ovaries variously verruculose; flowers have three similar sepals, frequently clawed petals, a distinctly trilobed lip with the lateral lobes erect and the midlobe variously adorned with thickened veins, which in many taxa appear as longitudinal-radiating, sometimes prominent keels, and a basal, forcipate callus; the column is normally straight and provided with apical wings, which commonly embrace the isthmus that separate the lateral lobes from the midlobe. The perianth parts are frequently greenish or pale tan, with the lip cream-white, often provided with rose-purple stripes along the main veins. Populations of Encyclia corresponding to this scheme are broadly distributed in the Neotropics, from Florida, Mexico, and the West Indies, throughout Central America, to Argentina and Paraguay, occurring both in Andean and Amazonian South America (Table 1).

For plants located in Mesoamerica, which we have investigated more closely during the past few years, traditional taxonomic approaches to understanding Encyclia have shifted from broad views of species circumscriptions that considered many of the described species of Epidendrum and Encyclia from Mesoamerica as a single polymorphic alliance (Ames et al., 1935, 1936) to the recognition of a large number of finely split taxa (Withner, 1996). According to the different taxonomic treatments, the group of greenish Central American Encyclia includes 4 to 13 species. The use of broad concepts to avoid the difficulty of finding clear ways to distinguish between closely allied species reached its apex during the first half of the last century with the work by Oakes Ames and his co-workers at Harvard University. In their studies on the genus Epidendrum (including Encyclia) of North and Central America (Ames et al., 1936), they considered most of the species with medium-sized flowers and an orbicular midlobe of the lip as varieties of a single variable species, a broadly defined Epidendrum oncidioides Lindl. However, scrutiny of more material now available proved that this gross lumping of Central American species under a few of the oldest names is untenable (Dressler and Pollard, 1976; Withner, 1996; Dressler, 2004; Pupulin, 2005, 2006). At the same time, a finely split concept for this group is equally untenable. The relative paucity of specimens available for study, together with the adoption of unconfirmed geographical records and the pronounced polymorphism of many Central American species, induced some botanists to adopt an excessively fine approach, often relying on subtle differences in type specimens that do not hold up in comparison with broader series of records (Withner, 1998, 2001). In both approaches, the impossibility of fully appreciating the range of natural variation eventually drove taxonomists to nomenclatural inflation or, alternatively, to a general misunderstanding of species diversity. 
TABLE 1. Described species of Encyclia with greenish flowers.

\section{Species}

Encyclia acuta Schltr.

Encyclia acutifolia (Sw.) Nir

Encyclia alanjensis (Ames) Carnevali \& Romero

Encyclia alboxanthina Fowlie

Encyclia amanda (Ames) Dressler

Encyclia amicta (Lind. \& Rchb.f.) Schltr.

Encyclia angustiloba Schltr.

Encyclia argentinensis (Spegazzini) Hoehne

Encyclia aspera (Lindl.) Schltr.

Encyclia asperirachis Garay

Encyclia asperula Dressler \& Pollard

Encyclia bradfordii (Griseb.) Carnevali \& Ramírez

Encyclia brenesii Schltr.

Encyclia ceratistes (Lindl.) Schltr.

Encyclia chloroleuca (Hook.) Neumann

Encyclia confusa Menezes

Encyclia davidhuntii Withner \& de Fuente

Encyclia diurna (Jacq.) Schltr.

Encyclia expansa (Rchb.f.) Ortíz

Encyclia fehlingii (Sauleda) Sauleda \& Adams

Encyclia flava (Lindl.) Porto \& Brade

Encyclia fucata (Lindl.) Britt. \& Millsp.

Encyclia glandulosa (Kunth) Ortíz

Encyclia gonzalensis Menezes

Encyclia goyazensis Menezes ex Fowlie

Encyclia granitica (Lindl.) Schltr. Venezuela,

Encyclia guentheriana (Kränzl.) R.Vásquez

Encyclia guyanensis Carnevali \& Romero

Encyclia hunteriana Schltr.

Encyclia inaguensis Nash ex Britt. \& Millsp.

Encyclia leucantha Schltr.

Encyclia lineariloba Withner

Encyclia linearifolioides (Kränzl.) Hoehne

Encyclia longifolia (Barb.Rodr.) Schltr.

Encyclia maderoi Schltr.

Encyclia maravalensis Withner

Encyclia monticola (Fawc. \& Rendle) Acuña

Encyclia mooreana (Rolfe) Schltr.

Encyclia mapiriensis Kränzl.

Encyclia naranjapatensis Dodson

Encyclia nematocaulon (A.Rich.) Acuña

Encyclia odoratissima (Lindl.) Schltr.

Encyclia oncidioides (Lindl.) Schltr.

Encyclia ossenbachiana Pupulin

Encyclia pachyantha (Lindl.) Hoehne

Encyclia patens Hooker

Encyclia pauciflora (Barb.Rodr.)

Encyclia pedra-azulensis Menezes

Encyclia peraltensis (Ames) Withner

Encyclia picta (Lindl.) Hoehne

\section{Distribution}

Brazil, Venezuela

Jamaica

Panama

Brazil

Panama

Bolivia, Brazil, Paraguay, Peru, Venezuela

Bolivia, Ecuador, Peru

Argentina, Brazil, Paraguay

Colombia, Ecuador, Peru

Colombia

Mexico, Guatemala, Belize

Tobago, Trinidad, Venezuela

Costa Rica

El Salvador to Colombia and Venezuela

Belize to Brazil and Peru

Brazil

Belize, Guatemala, Honduras, Costa Rica

Colombia, Suriname, Venezuela

Colombia

Bahamas

Brazil, Venezuela

Bahamas, Cuba

Colombia, Venezuela

Brazil

Brazil

Guyana, Suriname, Brazil

Bolivia

Venezuela, Guyana, Suriname

Panama

Bahamas, Turks and Caicos Islands

Colombia, Venezuela

Mexico. Guatemala, Nicaragua

Brazil

Brazil

Colombia

Trinidad

Cuba, Hispaniola. Jamaica, Trinidad

El Salvador to Panama

Brazil

Ecuador

Mexico to Nicaragua, and Cuba

Brazil

Brazil

Costa Rica

Venezuela, French Guyana, Guyana, Brazil

Brazil

Porto \& Brade Brazil

Brazil

Costa Rica

Guyana 
Table 1. Continues.

Species

Encyclia piracanjubensis Menezes

Encyclia porrecta B.R.Adams \& P.J.Cribb

Encyclia powellii Schltr.

Encyclia purpusii Schltr.

Encyclia recurvata Schltr,

Encyclia saltensis Hoehne

Encyclia sclerocladia (Lindl. ex Rchb.f.) Hoehne

Encyclia steinbachii Schltr.

Encyclia stellata (Lindl.) Schltr.

Encyclia tampensis (Lindl.) Small

Encyclia tarumana Schltr.

Encyclia thrombodes (Rchb.f.) Schltr.

Encyclia tonduziana Schltr.

Encyclia trachypus Schltr.

Encyclia triangulifera (Rchb.f.) Acuña

Encyclia tripartita (Vell.) Hoehne

Encyclia tuerckheimii Schltr.

Encyclia viridiflava Menezes

Encyclia wageneri Schltr.

Encyclia xerophytica Pabst.

Encyclia xypheres (Rchb.f.) Schltr.

Encyclia yauaperyensis (Vell.) Hoehne

Encyclia yucatanense Schltr.

Epidendrum affine Focke

Epidendrum chloranthm Lindl.

Epidendrum halatum Garay \& Dunsterv.

Epidendrum glutinosum Scheidw.

Epidendrum ramonense Rchb.f.

Epidendrum serronianum Barb.Rodr.

Epidendrum spectabile Focke
Distribution

Brazil
Belize
Panama
Mexico
Venezuela to Brazil
Brazil
Peru
Bolivia
Costa Rica to Colombia and Venezuela
Florida, Bahamas
Brazil
Bolivia, Peru, Brazil
Costa Rica
Ecuador
Cuba
Brazil
Mexico to Nicaragua
Brazil
Venezuela
Brazil
Mexico
Bolivia, Brazil
Mexico
Venezuela
-
Venezuela
Brazil
Costa Rica
Brazil
Venezuela

\section{Size (of the sample) matters}

One should emphasize that more common species, even in the group of the greenish Encyclia, are usually less taxonomically problematic. Taxonomy based on morphological analysis still relies on the interpretation of putative disjunctions along continuous variations of features, but this requires a representation of variation in character states as large as possible. In the Mesoamerican region, the ample records available for species such as Encyclia ceratistes (Fig. 5) or E. mooreana (Fig. 6) allow botanists not only to understand variation better, adopting sharper species circumscriptions and correctly interpreting heterotypic synonyms, but also detect those sister species that do not fit well any of the known specific patterns (Pupulin, 2006; Table 2).
A particularly critical situation is posed by taxa that span great geographic areas. As previously noted, floristic treatments have been mostly published on a national scale, and species comparison has been in many cases limited to the taxa recorded in immediately adjacent countries. Due to their overall diversity, the orchid floras of Central and South America have seldom been critically compared. It is a normal assumption that the patterns of geographic distribution in the Orchidaceae are generally defined by major continental masses, and the lack of generalist orchidologists has prevented in-depth monographic work spanning the whole Neotropics. When preparing a revision of Encyclia for the flora of Costa Rica (Pupulin and Bogarín, in preparation), we found one of these cases. Before the intensive field activity aimed at obtaining specimens for this study, E. amanda was known only 

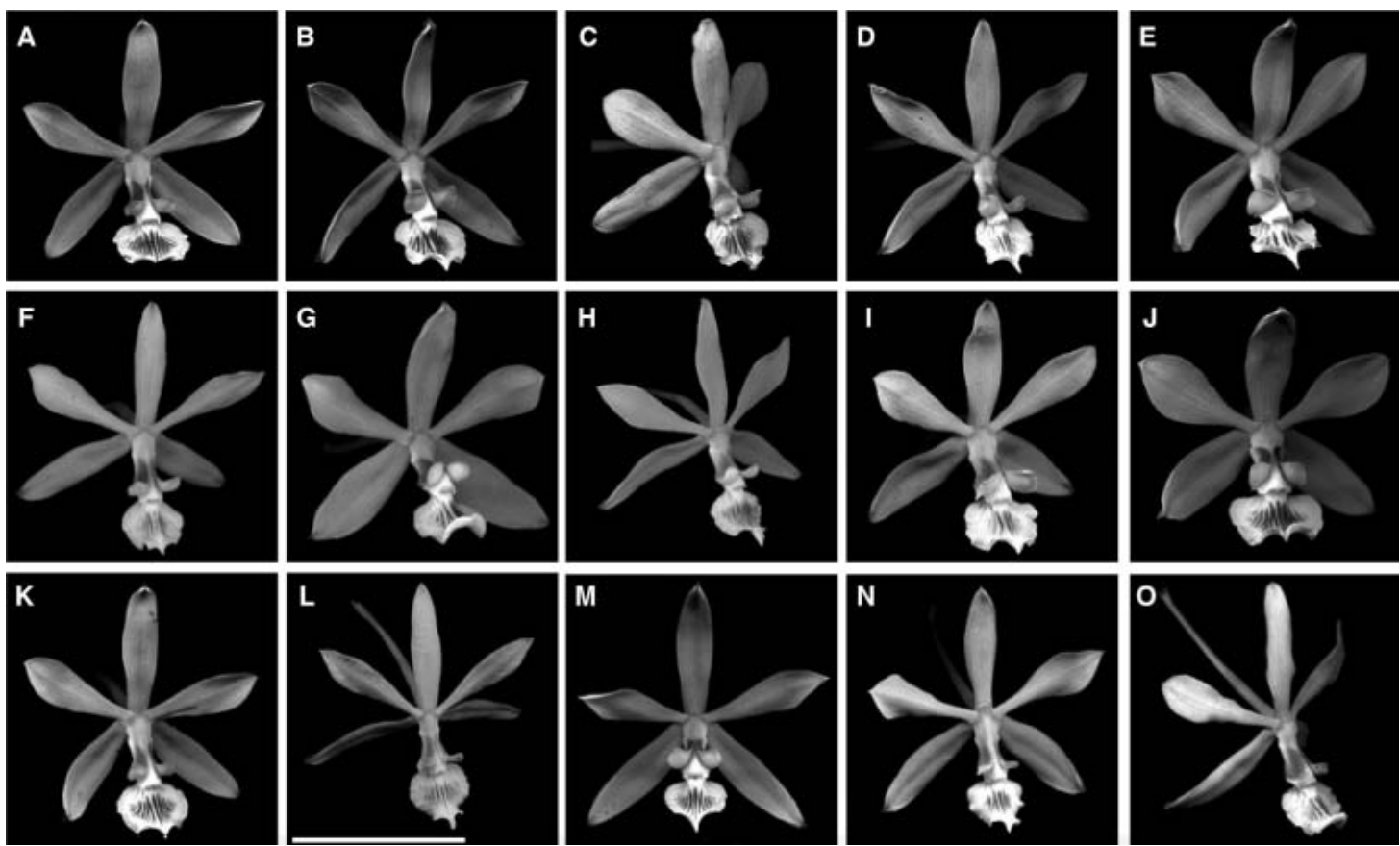

Figure 5. Floral variation in Encyclia ceratistes. A - Bogarín 3800; B - Bogarín 3799; C - Bogarín 3896; D - Bogarín 3797; E - Bogarín 3798; F - Pupulin 5641; G - JBL-s.n.; H - Pupulin 5200; I - Bogarín 5520; J - Bogarín 3806; K - Bogarín 3805; L - Pupulin 5303; M - Bogarín 3803; N - Pupulin 5641; O - Bogarín 3802. All the vouchers at JBL-Spirit. Scale bar $=2 \mathrm{~cm}$.
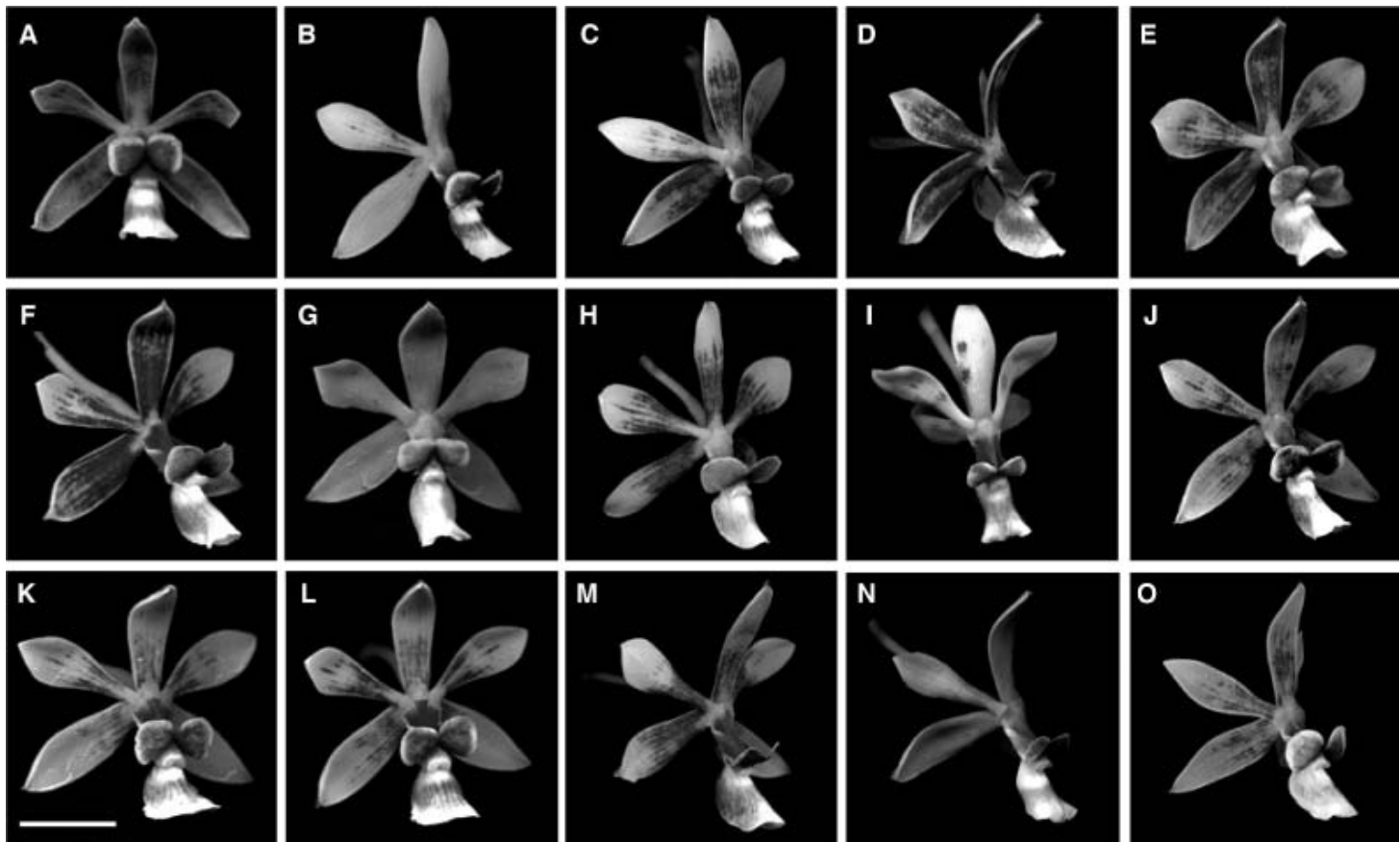

FiguRE 6. Floral variation in Encyclia mooreana. A - Bogarín 3810; B - JBL-06301; C - Bogarín 3721; D - JBL-08705; E - Bogarín 3787; F - Karremans 1356; G - JBL-08701; H - Gómez 3; I - Bogarín 3792; J - JBL-08704; K - Bogarín 3790; L - Bogarin 3791; M - JBL-08708; N - JBL-10044; O - JBL-08707. All the vouchers at JBL-Spirit. Scale bar = $1 \mathrm{~cm}$. 
TABLE 2. Comparison between taxonomic classifications of Costa Rican greenish Encyclia.

\begin{tabular}{|c|c|c|c|c|c|}
\hline $\begin{array}{l}\text { Williams } \\
1946\end{array}$ & $\begin{array}{c}\text { Dressler \& Pollard } \\
1974\end{array}$ & $\begin{array}{c}\text { Dressler } \\
1983\end{array}$ & $\begin{array}{l}\text { Withner } \\
1998 \text { \& ss. }\end{array}$ & $\begin{array}{c}\text { Dressler } \\
2003\end{array}$ & $\begin{array}{l}\text { Pupulin \& Bogarín } \\
\text { (in prep.) }\end{array}$ \\
\hline \multirow[t]{3}{*}{$\begin{array}{l}\text { Epidendrum oncidioides } \\
\text { var. gravidum }\end{array}$} & \multirow{3}{*}{$\begin{array}{l}\text { Encyclia gravida } \\
\text { Encyclia alanjensis } \\
\text { Encyclia hunteriana }\end{array}$} & \multirow{3}{*}{$\begin{array}{l}\text { Encyclia amanda } \\
\text { Encyclia gravida }\end{array}$} & $\begin{array}{l}\text { Encyclia amanda } \\
\text { Encyclia davidhunthii }\end{array}$ & & Encyclia chloroleuca \\
\hline & & & $\begin{array}{l}\text { Encyclia gravida } \\
\text { Encyclia stellata }\end{array}$ & Encyclia stellata & $\begin{array}{l}\text { Encyclia gravida } \\
\text { Encyclia stellata }\end{array}$ \\
\hline & & & Encyclia peraltensis & Encyclia peraltensis & Encyclia peraltensis \\
\hline $\begin{array}{l}\text { Epidendrum oncidioides } \\
\text { var. ramonense }\end{array}$ & Encyclia ceratistes & Encyclia ceratistes & Encyclia ceratistes & Encyclia ceratistes & Encyclia ceratistes \\
\hline \multirow{3}{*}{$\begin{array}{l}\text { Epidendrum oncidioides } \\
\text { var. mooreamum }\end{array}$} & & Encyclia mooreana & Encyclia mooreana & Encyclia mooreana & Encyclia mooreana \\
\hline & Encyclia tuerckheimii & Encyclia tuerckheimii & Encyclia tuerckheimii & & \\
\hline & & & & & Encyclia ossenbachiana \\
\hline
\end{tabular}

from a limited number of specimens. Withner (1998) mentioned no more than eight collections in the world's herbaria and included Costa Rica in the species distribution with no specimen citation (Withner, 2001). On the basis of the studied records, he characterized the species by the few-flowered ( 4 or 5 ), inflorescences that barely surpass the length of the leaves. Our collections revealed that this taxon is common in Costa Rica (Fig. 7) but extremely variable both in plant architecture and floral morphology. Well-developed inflorescences are commonly paniculate, many-flowered (12-30) and $60-70 \mathrm{~cm}$ long, but juvenile specimens may flower with short, simple, few-flowered racemes to only $15 \mathrm{~cm}$ long. Flowers vary greatly both within and among populations, and cultivated specimens show that floral variation may be notorious even on the same specimen at different flowering times (Fig. 8). When this range of variation is taken in account, the common Costa Rican taxon is not distinguishable from South American specimens of Encyclia chloroleuca (which has nomenclatural priority), and the study of the type specimen of Epidendrum chloroleucum at Kew confirmed our suspicions (Fig. 9). However, on the basis of the materials at our disposition, it is quite possible that the name $E$. amanda should be maintained for a distinct species from Panama and, perhaps, northern Colombia. The taxonomy of the Andean and Brazilian taxa in the group is still in urgent need of revision, and we cannot judge at this point how many specific epithets from these regions should be reduced to synonymy with E. chloroleuca.

\section{Cleistogamous Encyclia}

Even more intriguing and taxonomically difficult are those cases in which materials are hard to find due to the intrinsic nature of the relevant species. Now that we are concluding our revision of Costa Rican Encyclia, we will accept the concept of E. gravida with some reservation concerning the application of the name and the real identity of this taxon. Lindley (1849) originally described Epidendrum gravidum on the basis of a Mexican collection by Hartweg (Hartweg s.n., the type!). The holotype at Kew (Fig. 10) consists only of a single inflorescence originally bearing four fruits (one of which was removed in 1923 and sent to Oakes Ames for study); the remaining sepals measure $10-11 \mathrm{~mm}$ in length and ca. $3 \mathrm{~mm}$ in width (Lindley, 1849; see also Carnevali et al., 1994). Lindley (1849) considered it a "mere botanical curiosity," and in the protologue he gave no information about the vegetative characters of the new taxon. Florally, it was characterized by the linear lateral lobes of the lip, the ovate, acute midlobe provided with thickened veins, and the column with stigmatic, inflexed wings. After the original description, the name has been mostly adopted to identify populations of E. stellata, which shares with E. gravida a distinctly papillate ovary and the presence of prominent veins on the lip, but in a few cases the material referred to seems to match the original concept of Lindley.

Cleistogamy is a breeding system defined as the production of permanently closed, self-pollinated 

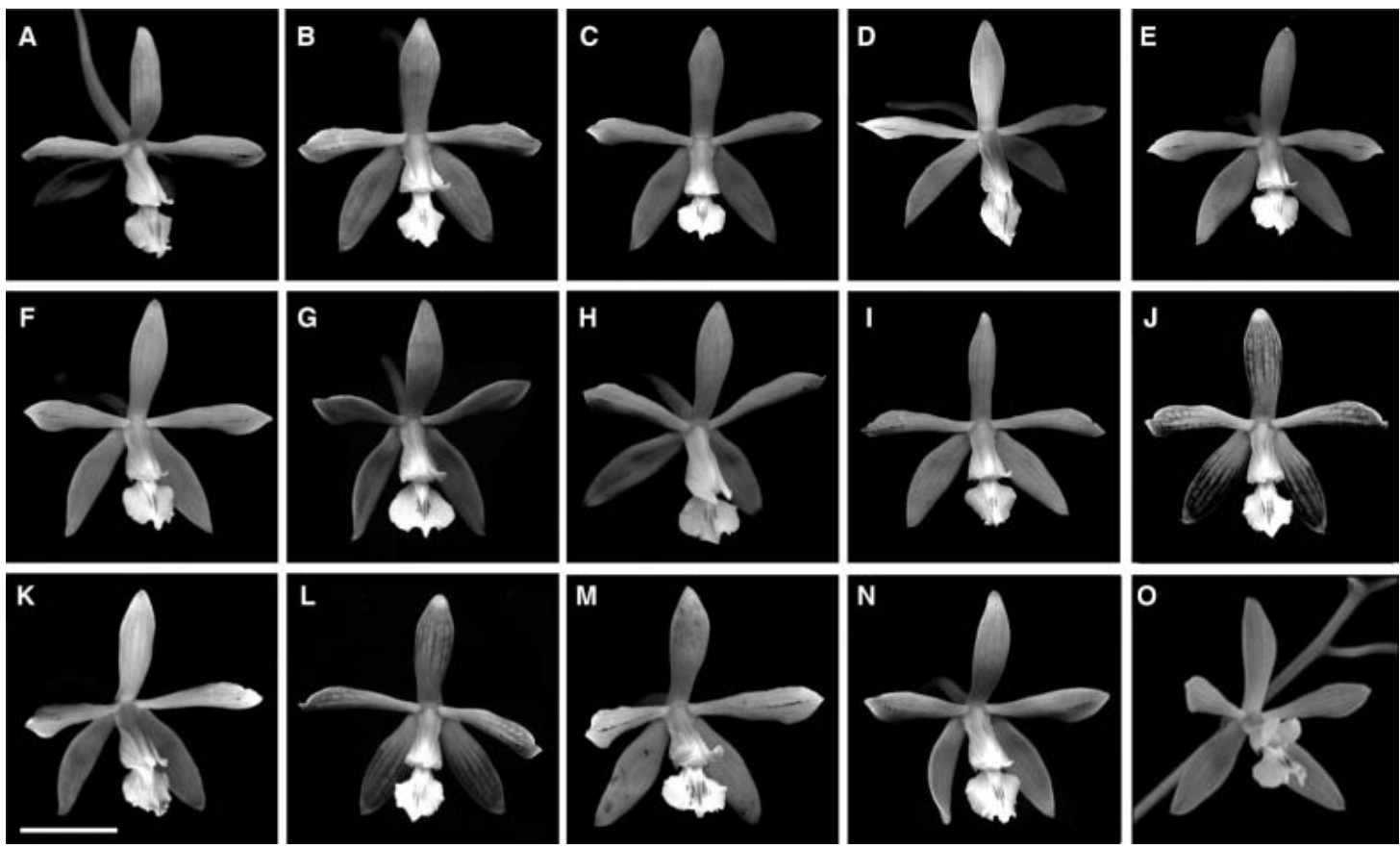

FIgURE 7. Floral variation in Encyclia chloroleuca. A - Bogarín 2537; B - Bogarín 2532; C - Bogarín 2537; D - Bogarín 3111; E - Bogarín 2544; F - Pupulin 3043; G - Ossenbach 365; H - Bogarín 2537; I - Bogarín 2544; J - Pupulin 3045; K - Pupulin 6536; L - Pupulin 3045; M - Pupulin 3045; N - Pupulin 3043; O - Pupulin 3044. All the vouchers at JBLSpirit. Scale bar $=1 \mathrm{~cm}$.

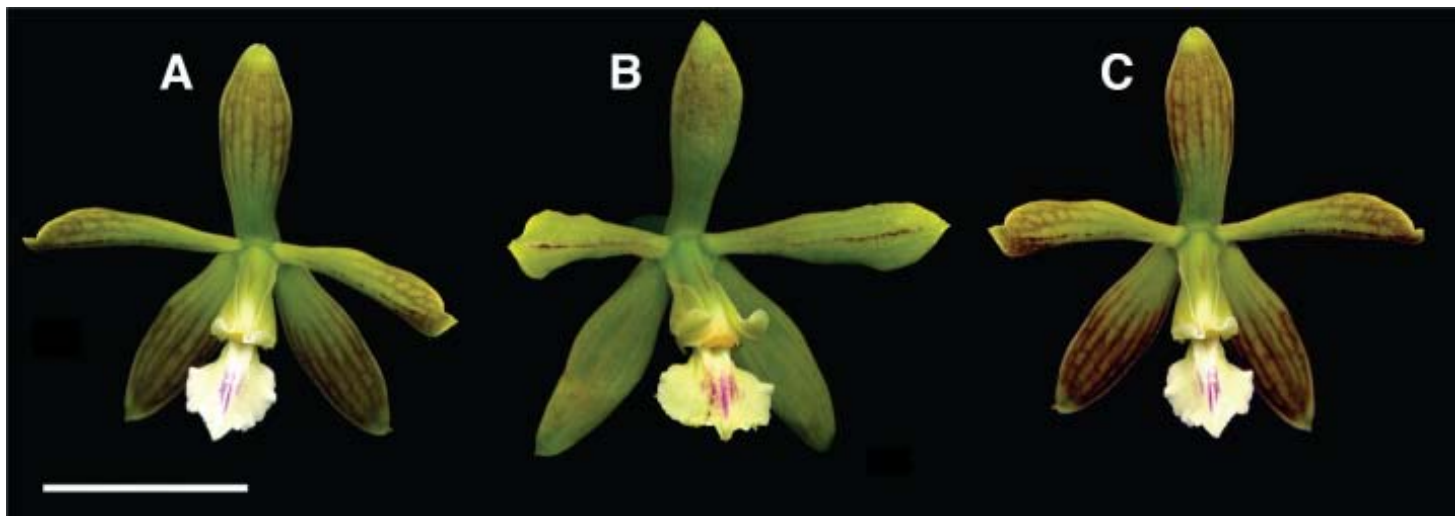

FIgURE 8. Floral variation in a single specimen of Encyclia chloroleuca. Pupulin 3045, flowering on 26 January 2003 (A),

11 June 2003 (B), and 3 March 2004 (C). Vouchers at JBL-Spirit. Scale bar $=1 \mathrm{~cm}$.

flowers, and it is now recognized as an important system found in a variety of plant taxa (Culley and Klooster, 2007). Fertilization within cleistogamous flowers occurs without the intervention of pollinators, and in the Orchidaceae this is usually accomplished by direct transfer of pollen grains from anther to stigma. In cleistogamous species, selfpollinating flowers may be the only type produced, but they may also appear together on the same plant along with typically insectpollinated flowers. Complete cleistogamy, defined as the production of only cleistogamous flowers on an individual, has been especially reported in orchid species, but most indications are based on observations of only a few individuals. 


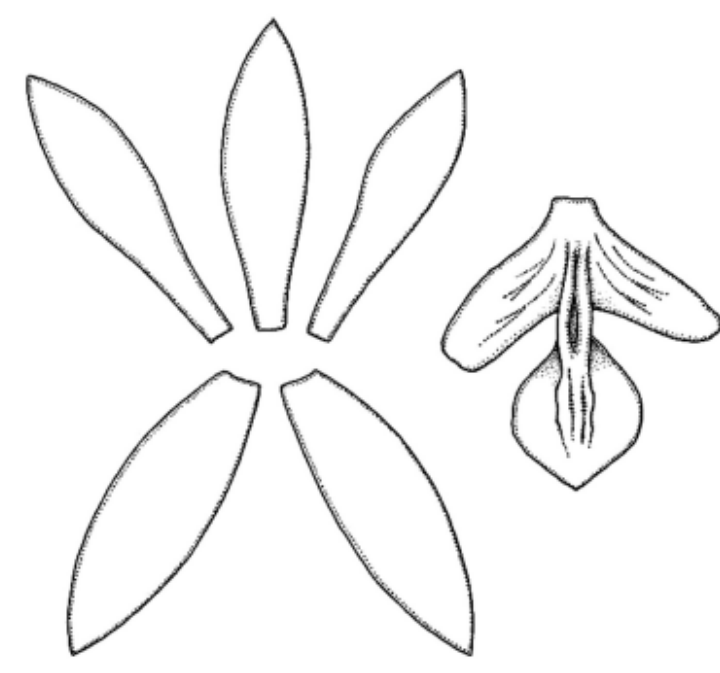

$1 \mathrm{~cm}$

FIgURE 9. Tracing of a flower from the holotype of Epidendrum chloroleucum. Drawn with the aid of a camera lucida by D. Bogarín.

There are obvious difficulties in documenting "true" cleistogamous Encyclia individuals. Plants of other species related to "E. gravida" are frequently pollinated in the wild, and the pollination rate is high for several taxa. In Costa Rica, where large populations of E. ceratistes are found in pristine and altered habitats, it is not uncommon to observe inflorescences bearing literally tens of fruits. As these individuals are vegetatively indistinguishable from cleistogamous forms, the only way to tell the two entities apart is a careful observation of the perianth parts. In true cleistogamous specimens, the ovary begins to swell and elongate while the buds are in their early stage of development and the sepals are still turgid when the fruit approaches maturity, whereas in allogamous, post-anthesis fecund flowers the perianth remains in place but begins to dry out a few days after pollination and becomes papyraceous with age. We found that there is no way to distinguish between the fruit of a cleistogamous plant and the developing fruit of a recent pollinated flower, the perianth of which is still turgid, without opening the perianth and looking at the remnant of the rostellum, which is completely absent in cleistogamous forms. This may perhaps explain why the number of documented specimens of 'gravid' encyclias is scanty.

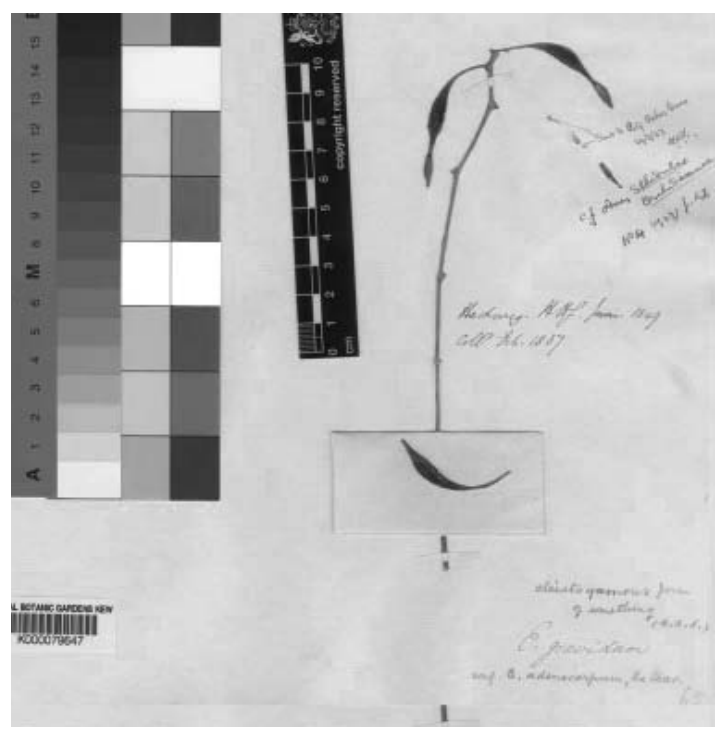

FIgURE 10. The holotype of Epidendrum gravidum. Reproduced with permission by the Board of Trustees, Royal Botanic Gardens, Kew.

Before World War II, Blanche Ames (Ames, 1923) illustrated the flower of another Mexican specimen collected by Purpus in Zacualpan, Veracruz, at that time kept in Schlechter's herbarium in Berlin but later destroyed (Fig. 11, A), which may correspond morphologically to the species originally described by Lindley. A Puerto Rican cleistogamous specimen was documented by Ackerman (1995), who noted that the perianth parts of the opened flower are not exactly zygomorphic, probably because of some constraint during development (Fig. 11, B). It is likely that another collection recorded by Schweinfurth (1940) from Maricao in Puerto Rico (Kevorkian 6177, AMES) belongs to this concept, because, according to the collector, the "flowers [...] does not open."

We have documented two cleistogamous specimens from plants growing in the living collections of Lankester Botanical Garden, University of Costa Rica. We had the plants growing under controlled conditions for a while, and cleistogamy in this case appears to be genetically controlled. Even though the two individuals share some of the morphological features expected for this taxon, they also differ in a number of characters, in particular the shape of the petals, the length of the labellar isthmus, the relative thickening of the veins on the midlobe, and the shape of the midlobe, which 

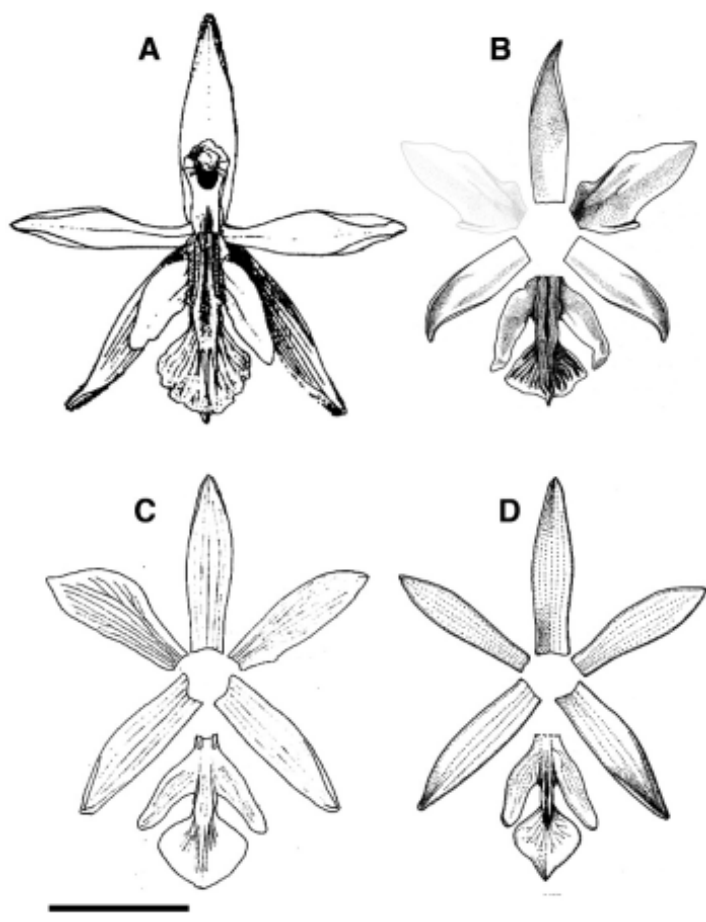

Figure 11. Cleistogamous Encyclia. A - Mexico, Purpus s.n., (B, destroyed); B - Puerto Rico; C - Costa Rica, Pupulin 6670 (JBL-Spirit); D - Costa Rica, Pupulin 5377 (JBL-Spirit). A, drawn by Blanche Ames, from Ames, 1923; B, drawn by M. Enríquez, from Ackerman 1995; C-D, drawn by F. Pupulin. Scale bar $=1 \mathrm{~cm}$.

is almost rhombic in one specimen and transversely ovate in the other (Fig. 11, C-D). More interesting is the fact that whereas one of the specimens lacks locality data, the other was collected in a region where only one other species of Encyclia, E. ceratistes, occurs naturally. During field work for the present treatment, we are making extensive collections of Encyclia specimens in this region, and to date we have observed only a single cleistogamous specimen. This may perhaps indicate that 'gravid' encyclias do not form populations, one of the essential requirements to be considered a good species, and are nothing more than occasional mutants.

When we compare the few documented specimens of cleistogamous Encyclia, it is evident that their similarity is superficial (Fig. 11, A-D), even when we could attribute these differences to some degree of deformity of the perianth parts, which do not spread out at the end of development. But which character (or set of characters) should properly define E. gravida?
Apart from the vegetative architecture, which is largely uniform in Encyclia species, and the features of the floral parts, which in turn vary considerably among individuals, the only shared character we observed in cleistogamous flowers is the absence of a definite rostellum, which would prevent the displacement of the pollen toward the stigmatic cavity. However, due to the paucity of available records of fecund plants of Encyclia to compare, this key feature alone is insufficient to assign cleistogamous individuals to a well-characterized species, and the possibility that the records simply represent self-pollinating forms belonging to different taxa cannot be discarded on the basis of floral morphology. The comparison of genetic sequences of individuals tentatively assigned to E. gravida with those of other sympatric species of Encyclia could represent an important step toward a better circumscription of the taxa in this group and the appreciation of the evolutionary significance of different pollination strategies.

\section{A case for barcoding}

In recent years, sequencing of plant genomes has been regarded as a powerful tool to assess the consistency of specific concepts and disclose cryptic taxa difficult to tell apart with traditional taxonomic methods, mainly through species DNA barcoding. However, even if at some stage clearly divergent barcodes can be used as the basis for nomenclatural decisions, barcodes by themselves are insufficient to describe new species. Species descriptions are scientific hypotheses that should be supported by a variety of other, including non-molecular, data sets. One of the necessary steps to place barcoding within the context of a rich taxonomic approach is the analysis of the range of intra- and interspecific variations in morphological characters, helping to prioritize which morphospecies and which individuals in problematic species complexes should be sequenced.

Application of the same species concept in taxonomically difficult groups like Encyclia, where hybridization may be frequent and occur over large areas, is still debatable (see Dressler and Pollard, 1976). DNA-based techniques may represent a unique opportunity to improve and simplify our hypotheses about species, but it is advisable they be used together with other disciplines such as phylogeography, 
comparative morphology, population genetics, ecology, development, and pollination biology to delimit the units of orchid diversity.

ACKNOWLEDGMENTS. Gratitude is expressed to the scientific services of the Costa Rican Ministry of Environment, Energy and Telecommunications (MINAET) and its National System of Conservation Areas (SINAC) for issuing the collecting permits under which wild species treated in this paper were collected and for variously assisting during field activity. The curators and staff at AMES, CR, K, SEL, and $\mathrm{W}$ are acknowledged for their courtesy and support during our visits and stays. The present work is part of the Project 814-A7-015, "Inventario y taxonomía de la flora epífita de la región Neotropical - Orchidaceae," sponsored by the Vice-Presidency of Research, University of Costa Rica.

\section{LiTERATURE CITED}

Ackerman, J. D. 1995. An orchid flora of Puerto Rico and the Virgin Islands. Mem. New York Bot. Gard. 73: iii-203.

Ames, O. 1923. Additions to the orchid flora of Central America with observations on noteworthy species. Schedul. Orch. 4: 1-62.

Ames, O., Hubbard, F. T., and Schweinfurth, C. 1935. A fourth polymorphic alliance in Epidendrum. Bot. Mus. Leafl. (Harvard University) 3: 93-112.

Ames, O., Hubbard, F. T., and Schweinfurth, C. 1936. The genus Epidendrum in the United States and middle America. Botanical Museum, Cambridge, UK.

Carnevali, G., Ramírez, I. M., and Romero, G. A. 1994. Orchidaceae Dunstervillorum VIII: species and combinations from Venezuelan Guayana. Lindleyana 9: 59-70.

Culley, T. M. and Klooster, M. R. 2007. The cleistogamous breeding system: a review of its frequency, evolution, and ecology in angiosperms. Bot. Rev. 73: 1-30.

Dressler, R. L. 1961. A reconsideration of Encyclia (Orchidaceae). Brittonia 13: 253-266.

Dressler, R. L. 1984. La delimitación de géneros en el complejo Epidendrum. Orquídea (Mexico City) 9: 277298.

Dressler, R. L. 2004. A key to the Central American species of Encyclia. Orch. Digest 68: 88-91.

Dressler, R. L. and Pollard, G. E. 1971. Nomenclatural notes on the Orchidaceae. IV. Phytologia 21: 433-439.

Dressler, R. L. and Pollard, G. E. 1974. The genus Encyclia in Mexico. Asociación Mexicana de Orquideología, Mexico City, Mexico.

Higgins, W. E. 1997 [1998]. A reconsideration of the genus
Prosthechea (Orchidaceae). Phytologia 82: 370-383.

Higgins, W. E., van den Berg, C., and Whitten, W. M. 2003. A combined molecular phylogeny of Encyclia (Orchidaceae) and relationships within Laeliinae. Selbyana 24: 165-179.

Hooker, J. D. 1828. Encyclia viridiflora. Curtis's Bot. Mag. 55: pl. 2831.

Lindley, J. 1831. Encyclia. Genera and species of orchidaceous plants, 111. Ridgways, London, UK.

Lindley, J. 1842. Epidendrum. Edwards's Bot. Reg. 28: 2736.

Lindley, J. 1849. New plants, etc. from the Society's garden: 13. Epidendrum gravidum. J. Hort. Soc. London 4: 11.

Lindley, J. 1853. Folia Orchidacea. Epidendrum. J. Matthews, London, UK.

Pupulin, F. 2005. Encyclia Hook. In Vanishing beauty native Costa Rican orchids 1 (ed. F. Pupuli), pp. 256-267. Editorial de la Universidad de Costa Rica, San José, Costa Rica.

Pupulin, F. 2006. Encylia ossenbachiana (Orchidaceae: Laeliinae), a new species from Costa Rica. Selbyana 27: 4-7.

Schlechter, R. 1914. Encyclia Hook. In Schlechter, R., Die Orchideen, pp. 207-212. Paul Parey, Berlin, Germany.

Schlechter, R. 1918. Kritische Aufzaehlung der bisher aus Zentral-Amerika bekanntgewordenen Orchideen; E. Aufzaehlung der Gattungen und Arten, part II (Epidendrum-Stanhopea). Beih. Bot. Centralbl. 36: 421520.

Schlechter, R. 1922. Beiträge zur Orchideenkunde von Zentralamerika. I. Orchidaceae Powellianae Panamenses. Repert. Sp. Nov. Regni Veg. Beih. 17.

Schlechter, R. 1923. Beiträge zur Orchideenkunde von Zentralamerika. II. Additamenta ad Orchideologiam Costaricensem. Repert. Sp. Nov. Regni Veg. Beih. 19.

Schweinfurth, C. 1940. A notable extension of range of Epidendrum oncidioides var. gravidum. Bot. Mus.Leafl. (Harvard University) 8: 187.

Van den Berg, C., Higgins, W. E., Dressler, R. L., Whitten, W. M., Soto Arenas, M. A., Culham, A., and Chase, M. W. 2000. A phylogenetic analysis of Laeliinae (Orchidaceae) based on sequence data from internal transcribed spacers (ITS) of nuclear ribosomal DNA. Lindleyana 15: 96-114. Withner, C. 1996. The cattleyas and their relatives. Vol. 4. The Bahamian and Caribbean species. Timber Press, Portland, Oregon, USA.

Withner, C. 1998. The cattleyas and their relatives. Vol. 5 . Brassavola, Encyclia, and other genera of Mexico and Central America. Timber Press, Portland, Oregon, USA.

Withner, C. 2001. Encyclia in Zentralamerika, zwei neue und sechs wenig bekannte Arten. Orchidee (Hamburg) 52: 444-450. 